\title{
Gap Analysis Sectoral Shares Index during the Covid-19 Pandemy on the Indonesia Stock Exchange
}

Oleh:

\author{
Sunarso Sunarso, Eswanto Sugeng Rahayu, Taufik Taufik, Irwan Kurniawan \\ sunarso12345678@gmail.com ${ }^{1)}$, eswantosr@gmail.com ${ }^{2}$, \\ alwitaufik@yahoo.com ${ }^{3)}$, h_irwan74@yahoo.co.id ${ }^{4)}$ \\ Sekolah Tinggi Ilmu Ekonomi IPWI Jakarta1),2),3),4)
}

Submit: 11 Nov $2020 \quad$ Review: 09 Dec $2020 \quad$ Accept: 21 Dec $2020 \quad$ Publish: 23 Dec 2020

\begin{abstract}
The investment risk during the Covid-19 pandemy is difficult to calculate due to increasing uncertainty. The research presents a model that can be used in mitigating short-term investment risk during the Covid-19 Pandemy on the capital market with sectoral gap return base on the difference price between the highest position and the lowest position. The gap may indicate volatility, volume inequality, price abnormalities, directional anomaly, and transaction conspiracy. This paper focused on how to manage portfolio investment risk based on short-term risk mitigation base on gap Analysis of sectoral return compare to Composite Index. The aim to be achieved was to minimize the risk of short-term portfolio investment at the start of the short-term Pandemic in Januari 2020 to August 2020. The specific target to be achieved in this study is to present a model that can increase the yield of short-term investments in the Indonesia Stock Exchange with low level of risk. The object of this research was sectoral idex of stock price whose price movements are in the opposite direction to the composite stock price index. The result of this research shown that the highest gap was basic Industry sector 54,50\%. Meanwhile, the lowest gap was trade sector 13,06\% followed by consumer sector 22,25\%. The higher the gap the bigger the risk.
\end{abstract}

Keywords: Mitigation Model, Investment Risk, Stock Portfolio, Covid-19

\section{BACKGROUND}

Price valuation of share price during Covid-19 pandemic is very needed to reduce risk of loss. Almost all companies' shares down during covid-19 pandemy so that before decide to by the shares, the sharer's price must be evaluated to find best portfolio as a part of risk mitigation during Covid-19 pandemy. (Alhazami, 2020).

Investment in stock market during pandemic cofid-19 has never been predicted by investors because such condition never happened before, no investor experienced such condition previously. That is why, investing in the stock market during the Covid-19 pandemic cannot be treated under normal risk level. One way to reduce investment risk is to mitigate unpredicted risks effectively (Andrew, Mamaysky \& Jiang, 2000).

Base on this unpredicted risk level, we consider new risk mitigation specialty designer under ubnormal risk level. Adjustment of risk management during 
pandemic cofid-19 will help in managing stock portfolio in new normal risk. This is done in order to avoid potential losses to investors. It is hoped that this risk mitigation can be used as an analytical tool in stock-based investment on the Indonesia Stock Exchange (IDX). Currently, the risk of investing in stock-based portfolios is still a cause of doubt for potential investors to invest in the IDX, so there is a need for education to investors and potential investors so that they can mitigate risks properly

This research is intended to find a risk mitigation model in investing of stockbased portfolios in the capital market such as market volatility during the Covid-19 pandemic. Stock-based portfolio investment has a high level of risk, especially during the Covid-19 Pandemic, so it is necessary to mitigate risks before investors decide to buy shares. This is due to many factors that influence stock prices, both internal and external factors amidst conditions of uncertainty.

The new sides of this research are risk gap and return gap approuce among main sectors in capital market, in this case BEI. As long as we obserb, this approuce is different from previous.

Base on some references, the abnormal returns were found in the Basic Industry and Chemicals sector, Infrastructure, Utilities and Transportation sector, Agricultural sector and Mining sector (Dilla, Sari \& Achsani: 2020). Covid 19 has an impact on the financial sector, capital market and the real sector such as public transportation, tourism, hospitality, offline retail, shopping centers, transportation of people and goods (Taufik \& Ayuningtyas: 2020). However, even though during the Covid-19 Pandemic the investment risk increased, each share had special characteristics and could not be generalized so that it required special treatment in managing its risks. The differences in the characteristics mentioned above are one of the basic considerations before making investment decisions on stock-based portfolio investments. By investing with a good understanding of risk mitigation, it is hoped that it will reduce doubts in investing based on shares, even during the Covid-19 Pandemic.

This research is based on previous research and expected to lay the basics of effective investment risk management by mitigating the risk of stock-based portfolio investmentch which started from a study of the phenomena that occurred in the pattern of stock price movements that occurred on the Indonesia Stock Exchange during the Covid-19 Pandemic. This phenomenon can be detected by analyzing the patterns of transactions on each share listed on the Indonesia Stock Exchange. After the analysis of transaction patterns is carried out, several indicators can be used to mitigate risk (Sunarso, 2015).

In this research, a graphic patternbased risk mitigation model is used which is the most responsive visual risk measurement method when the market is volatile. The first step is identifying chart patterns. The second step is to pair the two patterns in one momentum. The third step is to create a scenario after the investment decision is made.

In the next phase of the study, further studies will be carried out and the possibilities of applying new risk measurement indicators to the risk mitigation-based portfolio investment strategy on the Indonesia Stock Exchange

This research is expected to produce an investment risk management model that can be used as a reference in developing portfolio investment theory which can be used by investors in mitigating investment 
risk. By mitigating these risks, investors can not only arrange their investment portfolios more safely, but also take anticipatory action according to the level of risk that occurs. Risk mitigation will also be able to limit losses and optimize returns. This will ultimately increase public interest in investing in the stock market, even during the Covid-19 Pandemic.

The mainly of this research problem can be stated as follows: How to manage risk mitigation-based investments on the IDX today The Covid-19 Pandemic?, How to implement an effective risk mitigation model IDX during the Covid-19 Pandemic?, How to get the optimal return on investment at the price down due to the Covid-19 pandemic?, How to convert a losing position into a deep profit position Transacting shares on the IDX during the Covid-19 Pandemic?

The objective of this research is to present a new model for mitigating the risk of stock investment during the Covid-19 Pandemic. This model ia not just repeatation of previous model in normal condition, but try to present new model in mitigating investment risk under abnormal condition in order to manage risk that never predicted before. As we now, previous risk management concerns only analyse fundamental and technical factors so that can't be applied under extreem condition such as cofid-19 Pandemic.

The effective model of managing risk investnent of shares according to this extreem risk, can be simplify in this investment risk mitigation. This goal is achieved through several stages, starting from identifying and classifying stocks listed on the Indonesia Stock Exchange according to their risk level based on stockbased investment risk mitigation. With this risk mitigation, it will provide a basis for decision making, especially for investors and potential investors.

\section{RESEARCH METHOD}

This research method was set under specific condition. Investment risk mitigation during normal condition contains 8 steps, no. to number 8 . In this research We set in new normal during pandemic condition by investigating sectoral indexes movement to specify sectoral prices' gap. First of all, risk calculating by subtracting the highest level with the lowest level. This result a number that indicate risk level. The higher number the higher risk level. Secondly, choosing the lowest gap of all sectoral indexes. This will reduce risk of Investment in ubnormal risk level in the pandemic cofid-19. The third, removing stocks that have an expected return below risk level. This will give higher expected return than risk opportunity.

The above three steps are relatively new in risk mitigation. The steps are modified according to extreem risk is the uncertainty of an event that will occur in the future as a result of decisions made at this time based on certain considerations. Investment risk is unavoidable, but can be managed by carefully mitigating risks. So, it can be said that risk mitigation is a means to overcome the unexpected consequences of a decision taken. Decisions are made now, but the consequences of these decisions are related to the uncertainty of future results.

The risk mitigation as we discuss before in the background must be understood by investors due to the fact tat decisions taken at this time, is necessary to carry out risk mitigation that is effective and efficient regardless of the object and consideration. In portfolio investment in 
the capital market, the uncertainty of investment returns due to today's decisions needs to be anticipated by mitigating risk. Risk occurs if the expected investment return does not match the investor's expectations. Risk in normal conditions is linearly related to the yield. The higher the risk of shares, the higher the expected return (Saleh: 2009).

Based on the results of the research on the cluster formed above, there is no correlation between risk and return. Under normal conditions, the higher the risk, the higher the potential return. However, in abnormal conditions, during the Covid-19 Pandemic, the conditions that occurred were high risk of low yield and often low risk of high yield. This research is an experimental study so that it does not discuss the correlation theory between risk and return, but leads to an

The object of the research were main sectoral indexes. The analysis techniques in this study using gap analysis. Gap analysis is the grouping of a set of objects into two or more groups based on the range from the highest to the lowest. In this case based on the level of risk of a security. Cluster analysis is a multivariate technique which has the main objective of classifying objects based on their characteristics. Cluster analysis classifies objects.

The selection of stocks in one cluster is based on the frequency of repeating graphic patterns within one month prior to the research period. In principle, clustering classifies objects into clusters according to the characteristics of the object. The clusters formed reflect the similarities and closeness of the characteristics attached to the object under study. In this case the proximity of the time the chart pattern repeats monthly.

There are two important processes in cluster formation, namely the determination of the cluster profile and the number of clusters. The two things mentioned above have a decisive role both in the results obtained and in the interpretation of the research results.

The determination of the gap was calculated by subtracting the highest position with the lowest position. The research stage began with the listing of issuers that experienced a cumulative price increase from January 2020 to August 2020, which consisted of all sectors listed on the Indonesia Stock Exchange. Furthermore, historical data collection, risk assessment and risk clustering. The research data is secondary data sourced from daily transaction data on the Indonesia Stock Exchange which is accessed online through Mirae Asset Securities.

\section{RESEARCH RESULTS}

\section{Risk Management-based Portfolio Investment Risk Mitigation}

Base on implementation of investment risk management we found very extreem different among sectoral indexes, so that it can provide variety of profil and lost to investors depend on the position even though it does not reach a recommendation to buy or sell shares like research conducted by securities companies, that treat all stocks as under normal condition.

Based on the identification of graphic pattern models, during the Covid-19 Pandemic, several repetitions of graphic patterns were found.

\section{Sectoral Index Gap Data}

The sectoral gap index is used in investment risk analysis although it is rarely a concern of stock analysts and academic researchers. Only active practitioners or investors usually use this analysis to look for opportunities when the 
Composite Stock Price Index is down. Sectoral inequality indications are analyzed by looking at price movements. If the direction is opposite or move unproportional to the direction of the JCI, it means that there is a sector gap.

\section{Composite Index Gap}

The Composite Index highest return was 4,98\% reached in July 2020. The lowest return was $-16,76 \%$, reached in March 2020 . So the gap was 21,74 . It means that the potential risk was $21,74 \%$ as sown on the table 1.

Table 1. Composite Index Return

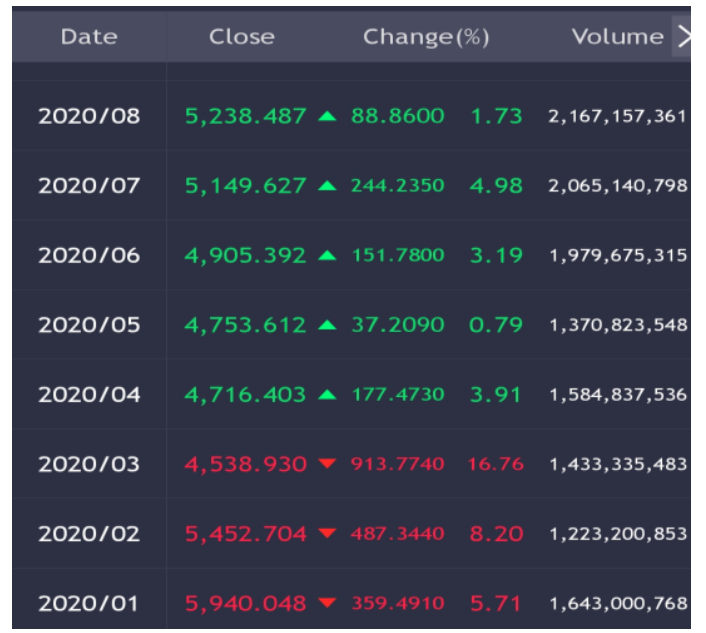

\section{Agricultur Sector Index Gap}

The Agriculture Sector Index highest return was 12,54\% reached in July 2020. The lowest return was $-11,57$ reached in March 2020, So, the gap was 24,11 It means that the potential risk was $24,11 \%$ as sown on the table 2 .

\section{Mining Sector Index Gap}

The Mining Sector Index highest return was 11,95\% reached in July 2020. The lowest return was $-11,57 \%$. So the gap was 23,52 as sown on the table 3 .
Table 2. Agriculture Index Return

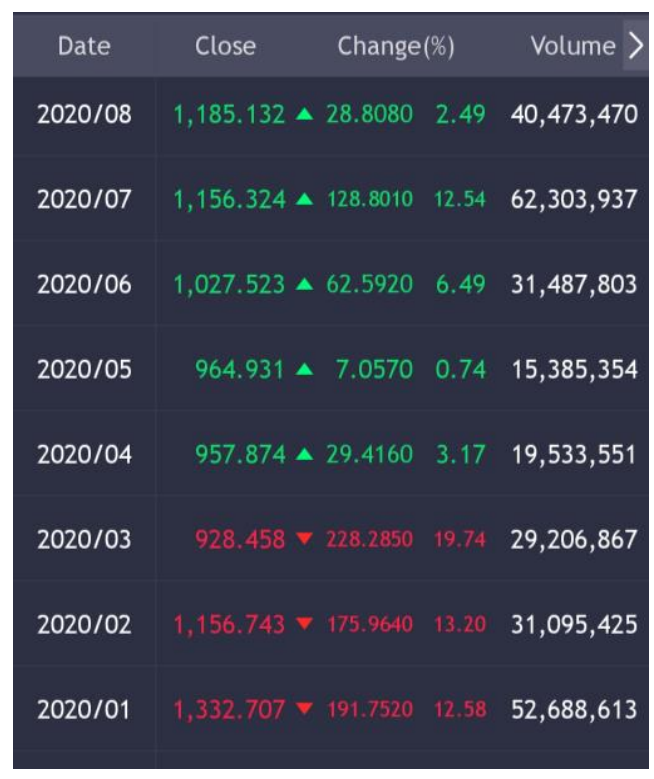

Table 3. Mining Sector Index Gap

\begin{tabular}{|c|c|c|c|c|}
\hline Date & Close & \multicolumn{2}{|c|}{ Change(\%) } & Volume > \\
\hline $2020 / 08$ & $1,398.809 \Delta$ & 28.6340 & 2.09 & $290,148,340$ \\
\hline $2020 / 07$ & $1,370.175 \Delta \Delta$ & - 146.2230 & 11.95 & $290,102,607$ \\
\hline $2020 / 06$ & $1,223.952 \nabla$ & 14.2490 & 1.15 & $227,903,203$ \\
\hline $2020 / 05$ & $1,238.201$ A & 29.2860 & 2.42 & $143,528,671$ \\
\hline $2020 / 04$ & $1,208.915 \Delta$ & 24.8210 & 2.10 & $219,330,036$ \\
\hline $2020 / 03$ & $1,184.094 \nabla$ & 154.9740 & 11.57 & $196,407,006$ \\
\hline $2020 / 02$ & $1,339.068 \nabla$ & 65.6720 & 4.68 & $197,092,798$ \\
\hline $2020 / 01$ & $1,404.740 \nabla$ & 143.8820 & 9.29 & $347,125,792$ \\
\hline
\end{tabular}

\section{Basic Industry Sector Index Gap}

The basic Industry sector Index highest return was 31,26\% reached in July 2020. The lowest return was $-23,54 \%$. So, the gap was 54,80 . as sown on the table 4 . 
Table 4. Basic Industry Index Return

\begin{tabular}{|c|c|c|c|c|}
\hline Date & Close & \multicolumn{2}{|c|}{ Change(\%) } & Volume > \\
\hline $2020 / 08$ & $760.257 \Delta$ & 8.1790 & 1.09 & $122,011,003$ \\
\hline $2020 / 07$ & $752.078 \Delta$ & 30.4130 & 4.21 & $180,285,005$ \\
\hline $2020 / 06$ & $721.665 \nabla$ & 24.0680 & 3.23 & $133,602,312$ \\
\hline $2020 / 05$ & $745.733 \nabla$ & 15.9290 & 2.09 & $60,850,409$ \\
\hline $2020 / 04$ & 761.662 A & 181.4000 & 31.26 & $100,114,278$ \\
\hline $2020 / 03$ & $580.262 \nabla$ & 178.4990 & 23.53 & $83,730,613$ \\
\hline $2020 / 02$ & $758.761 \nabla$ & 128.5010 & 14.48 & $79,529,183$ \\
\hline $2020 / 01$ & $887.262 \nabla$ & 90.8650 & 9.29 & $122,437,484$ \\
\hline
\end{tabular}

\section{Misc-Industry Sector Index Gap}

The Misc industri index highest return was $17,02 \%$ reached in July 2020. The lowest return was $-11,65 \%$. So the gap was $28,67 \%$ as sown on the table 5 .

Table 5. Misc-Industry Sector Index Gap

\begin{tabular}{|c|c|c|c|c|c|}
\hline Index & Daily & & \multicolumn{2}{|c|}{ Chart } & Stock > \\
\hline Daily & \multicolumn{3}{|c|}{ Weekly } & \multicolumn{2}{|c|}{ Monthly } \\
\hline Date & Close & & Change & (\%) & Volume $>$ \\
\hline $2020 / 08$ & 912.719 & $\checkmark$ & 9.0130 & 0.98 & $51,569,951$ \\
\hline $2020 / 07$ & 921.732 & $2 \Delta$ & 54.6080 & 6.30 & $44,264,986$ \\
\hline $2020 / 06$ & 867.124 & $4 \Delta$ & 8.7280 & 1.02 & $87,558,867$ \\
\hline $2020 / 05$ & 858.396 & 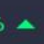 & 124.8610 & 17.02 & $36,920,499$ \\
\hline $2020 / 04$ & 733.535 & $5 \Delta$ & 0.5080 & 0.07 & $48,507,277$ \\
\hline $2020 / 03$ & 733.027 & 7 & 256.3610 & 25.91 & $54,804,736$ \\
\hline $2020 / 02$ & 989.388 & $\nabla$ & 130.4640 & 11.65 & $61,887,044$ \\
\hline $2020 / 01$ & $1,119.852$ & 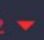 & 104.0010 & 8.50 & $49,250,433$ \\
\hline
\end{tabular}

\section{Consumer Sector Index Gap}

The consumer Sector Index highest return was 9,78\% reached in July 2020. The lowest return was $-11,57 \%$. So, the gap was $21,35 \%$ as sown on the table 6 .
Table 6. Consumer Sector Index Gap

\begin{tabular}{|c|c|c|c|c|}
\hline Date & Close & \multicolumn{2}{|c|}{ Change(\%) } & Volume > \\
\hline $2020 / 08$ & $1,933.176 \Delta \Delta$ & 47.1280 & 2.50 & $105,822,781$ \\
\hline $2020 / 07$ & $1,886.048 \Delta$ & 85.1510 & 4.73 & $115,168,027$ \\
\hline $2020 / 06$ & $1,800.897 \nabla$ & 5.8280 & 0.32 & $71,009,876$ \\
\hline $2020 / 05$ & $1,806.725 \nabla$ & 14.6630 & 0.81 & $49,109,900$ \\
\hline $2020 / 04$ & $1,821.388 \boldsymbol{\Delta}$ & 162.2500 & 9.78 & $55,127,780$ \\
\hline $2020 / 03$ & $1,659.138 \nabla$ & 83.8010 & 4.81 & $79,167,897$ \\
\hline $2020 / 02$ & $1,742.939 \nabla$ & 243.4310 & 12.26 & $53,830,590$ \\
\hline $2020 / 01$ & $1,986.370 \nabla$ & 66.2840 & 3.23 & $76,787,349$ \\
\hline
\end{tabular}

\section{Property Sector Index Gap}

The Property Sector Index highest return was 10,20\% reached in July 2020. The lowest return was $-20,77 \%$. So, the gap was $31,17 \%$. as sown on the table 7 .

Table 7. Property Sector Index Gap

\begin{tabular}{|c|c|c|c|c|}
\hline Date & Close & \multicolumn{2}{|c|}{ Change(\%) } & Volume > \\
\hline $2020 / 08$ & $297.393 \nabla$ & 3.1030 & 1.03 & $248,354,776$ \\
\hline $2020 / 07$ & $300.496 \nabla$ & 21.5440 & 6.69 & $351,810,368$ \\
\hline $2020 / 06$ & $322.040 \mathrm{v}$ & 0.9170 & 0.28 & $404,233,464$ \\
\hline $2020 / 05$ & 322.957 А & 29.9060 & 10.20 & $211,496,718$ \\
\hline $2020 / 04$ & $293.051 \nabla$ & 45.3600 & 13.40 & $335,126,990$ \\
\hline $2020 / 03$ & $338.411 \nabla$ & 88.7220 & 20.77 & $263,177,584$ \\
\hline $2020 / 02$ & $427.133 \mathrm{v}$ & 24.2130 & 5.36 & $227,429,416$ \\
\hline $2020 / 01$ & $451.346 \nabla$ & 52.5330 & 10.43 & $289,419,766$ \\
\hline
\end{tabular}

\section{Finance Sector Index Gap}

The Finance Sector Index highest return was 10,09\% reached in July 2020 . The lowest return was $20,78 \%$. So the gap was $30,87 \%$ as sown on the table 8 . 
Table 8. Finance Sector Index Gap

\begin{tabular}{|c|c|c|c|c|}
\hline Date & Close & \multicolumn{2}{|c|}{ Change(\%) } & Volume $>$ \\
\hline $2020 / 08$ & $1,185.068 \wedge$ & A 50.1390 & 4.42 & $406,673,711$ \\
\hline $2020 / 07$ & $1,134.929$ A & A 75.3360 & 7.11 & $319,147,045$ \\
\hline $2020 / 06$ & $1,059.593 \wedge$ & A 97.0780 & 10.09 & $331,635,059$ \\
\hline $2020 / 05$ & $962.515 \Delta$ & A 14.7350 & 1.55 & $479,320,686$ \\
\hline $2020 / 04$ & $947.780 \mathrm{~V}$ & > 41.8940 & 4.23 & $198,813,128$ \\
\hline $2020 / 03$ & $989.674 \vee$ & 259.6610 & 20.78 & $202,162,829$ \\
\hline $2020 / 02$ & $1,249.335 \vee$ & 67.0070 & 5.09 & $104,134,853$ \\
\hline $2020 / 01$ & $1,316.342 \nabla$ & $>38.3190$ & 2.83 & $202,699,469$ \\
\hline
\end{tabular}

\section{Trade Sector Index Gap}

The Trade Sector Index highest return was $2,78 \%$ reached in July 2020 . The lowest return was $-10,28 \% \%$. So, the gap was $13,06 \%$. as sown on the table 9 .

\section{Table 9. Trade Sector Index Gap}

\begin{tabular}{|c|c|c|c|c|}
\hline Date & Close & \multicolumn{2}{|c|}{ Change(\%) } & Volume > \\
\hline $2020 / 08$ & $628.751 \Delta$ & 5.7570 & 0.92 & $491,003,074$ \\
\hline $2020 / 07$ & 622.994 А & 16.8580 & 2.78 & $371,476,222$ \\
\hline $2020 / 06$ & $606.136 \nabla$ & 0.4970 & 0.08 & $394,216,025$ \\
\hline $2020 / 05$ & $606.633 \nabla$ & 0.3100 & 0.05 & $197,830,544$ \\
\hline $2020 / 04$ & 606.943 ^ & 4.6690 & 0.78 & $363,079,801$ \\
\hline $2020 / 03$ & $602.274 \nabla$ & 69.0140 & 10.28 & $312,547,918$ \\
\hline $2020 / 02$ & $671.288 \nabla$ & 51.4450 & 7.12 & $297,144,899$ \\
\hline 2020/01 & $722.733 \nabla$ & 47.0990 & 6.12 & $334,560,838$ \\
\hline
\end{tabular}

\section{Manufacture Sector Index Gap}

The Manufacture Sector Index highest return was $14,51 \%$ reached in July 2020 . The lowest return was $-14,06 \%$. So the gap was $28,57 \%$ as sown on the table 10 .
Table 10. Manufacture Sector Index Gap

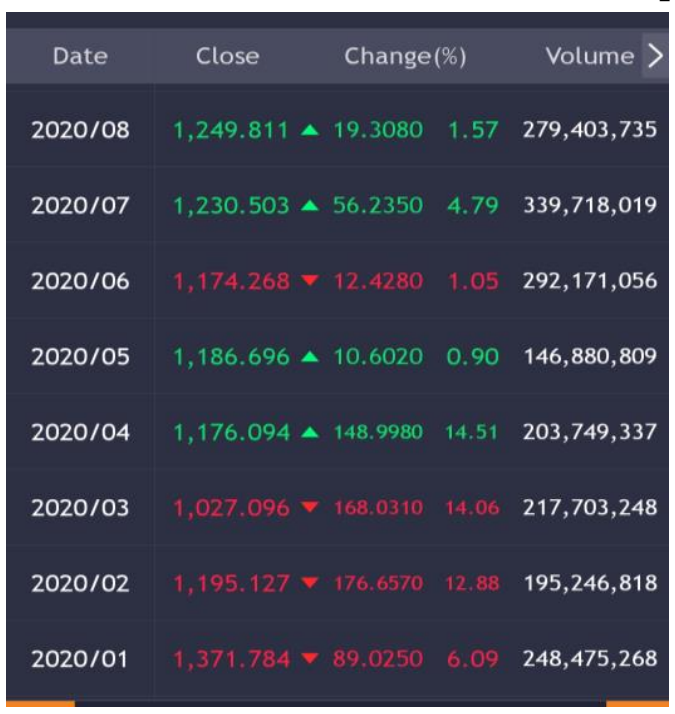

\section{Daily Fluctuation Data of Sectoral Share Prices}

To know the fluctuation of the stock price per sector is done with a candle stick diagram. The longer the higher the price volatility. The candle diagram is presented in figure 1.

Figure 1. Composite Index Chart

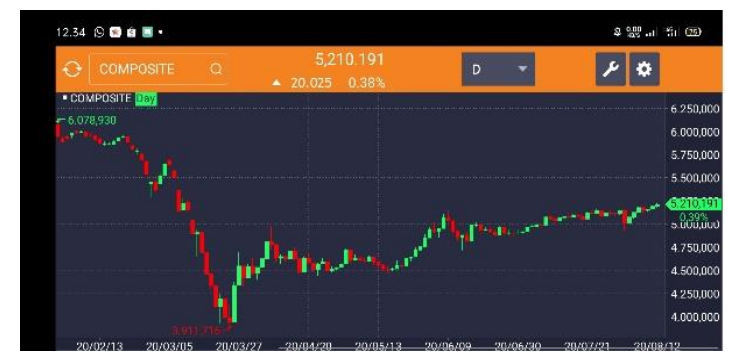

This research found facts that were rare discussed in the previous research by any one. Mostly those concerned on individual stocks rather than sectoral indexes. The sectoral risk mitigation will give direction to the investors to guide the safe sector before selecting individual stock or portofolio as in the normal condition. In the normal condition investors mostly oncern on technical and fundamental factors. 
The sectoral index movement indicate industrial strength or weakness during cofid-19 pandemy. Low volatility sectoral index movement refers the strength of the sector and high volatility sectoral index movement indicates the weakness of the sector. The volatility of the sectoral indexes can be sown by calculating gap between the highest return and the high lost presented in the table 11.

Figure 2. Sectoral Index Chart

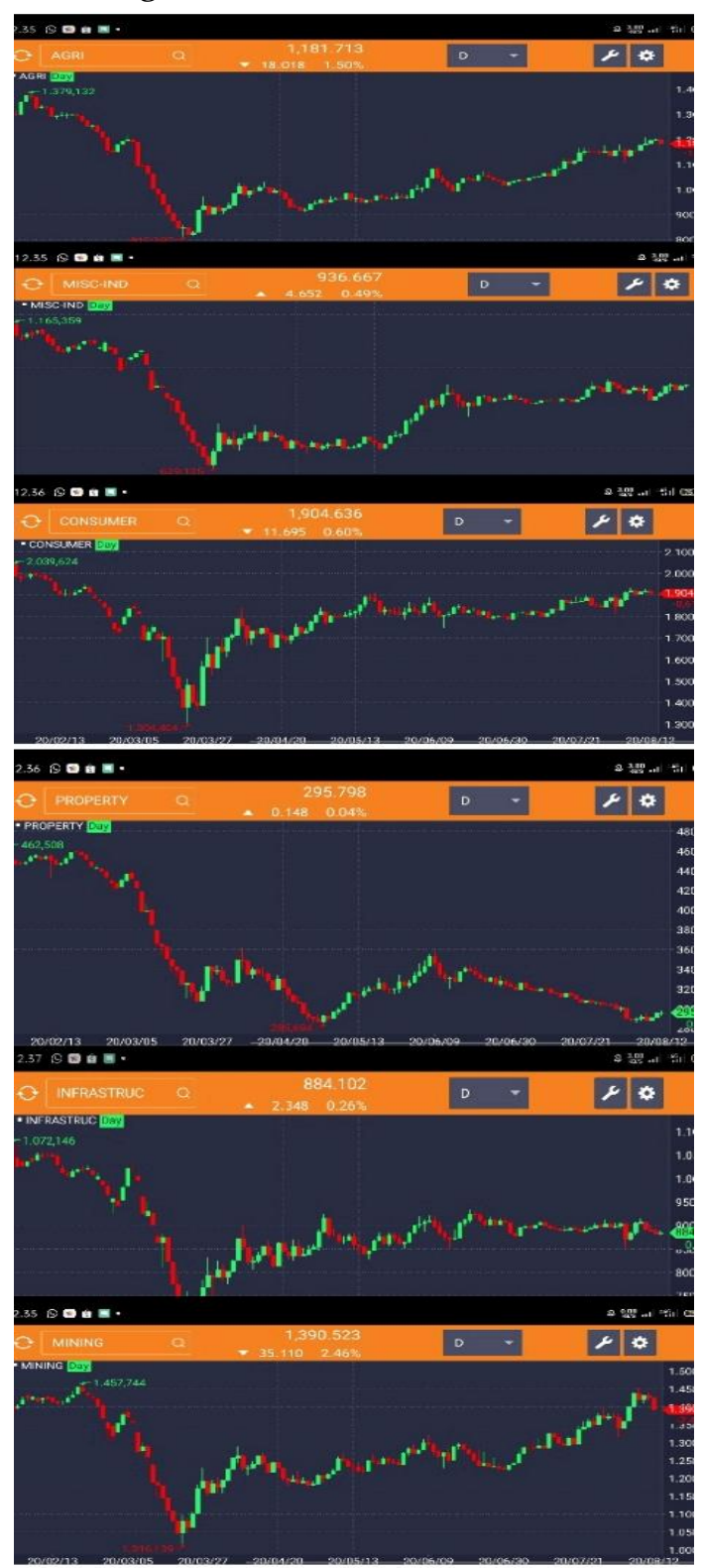

Table 10. Sectoral Index Gaps

\begin{tabular}{llll}
\hline Index & $\begin{array}{l}\text { High } \\
\text { Return }\end{array}$ & $\begin{array}{l}\text { High } \\
\text { Lost }\end{array}$ & Gap \\
\hline Composite & 4,98 & 16,76 & 21,74 \\
Agri & 12,54 & 11,57 & 24,11 \\
Mining & 11,95 & 11,57 & 23,52 \\
Basic Ind. & 31,26 & 23,54 & 54,80 \\
Mic. Ind & 17,02 & 11,65 & 28,67 \\
Consumer & 9,78 & 11,57 & 21,35 \\
Property & 10,20 & 20,77 & 31,17 \\
Finance & 10,09 & 20,78 & 30,87 \\
Trade & 2,78 & 10,28 & 13,06 \\
Manufacture & 14,51 & 14,06 & 28,57 \\
\hline
\end{tabular}

Base on the above facts, we find that trade and consumer good sectors have the first and the second lowest risk in general, indcated by lowest gap of trade sector only 13,96 and consumer goods that only $22,25 \%$. As we discuss above, consumer sector index highest return was 9,78\% reached in July 2020. The lowest return was $-11,57 \%$. So, the gap was $21,35 \%$.

According to above finding during the pandemic cofid-19, trade and consumer goods sector are the safest sectors for the investors. The explanation of our finding correspouds to the fact that trade and consumer goods are always needed by users under any condition include during covid-19 pandemy, especially farmacy, foods, and beverages.

\section{DISCUSSION}

The impact Covid-19 pandemy can not be separated from threat of global recession. Therefore, New Normal has improved the mood of capital market after the lowest on April-May 2020. JCI recorded a gain of $1.98 \%$ to $4,847.51$, which becomes the highest level during that periode (Rivai'i, Hasan \& Junaidi, 2020). 
Besides, a tentative explanation for this seem to finding that the impact of COVID19 in the stock markets of Asian countries has spill-over effects on European and American countries. The spill-overs appear to be related to the spread of COVID-19 and the shock, dear and panic among international investors (Qing, Junyi, Sizhu \& Jishuang, 2020).

According to nature of stocks' price characteric the reversal movement sooner or later will occure (Kiky, 2020). This can be said that the risk mitigation during pandemic can be discused briefly. Buy shares when the stock price fluctuates requires us to manage risks as efficiently as possible.

Base on our above discussion relate to the sectoral gap Analysis, the most efficient way in mitigating risk during ubnormal prices' movement ia to calculate gap of sectoral index. This does not mean that we do not have the opportunity to transact in stocks whose movements are very volatile. However, we should wait for the shares to have a discounted valuation so that they are not too expensive as seen from the PER and BV of similar companies. The profit target depends on the trend. In the short term, the $5 \%$ profit target on blue chip stocks is normal. If it hasn't reached $5 \%$ the trend stops less than $5 \%$ is also good. However, if the trend continues, buy back. The following is an example of a chart showing the fluctuation of stock prices which is the object of research.

In experimental transactions, the most volatile portfolio is deliberately chosen so that the turnover is fast, so that even though the transaction is carried out with a small number of lots, the frequency of transactions is high. The following is a chart of stock prices with highly fluctuating movements due to the impact of the Covid19 Pandemic.

Base on the above discussion we stated that gap sectoral index will lead investors to choose the lowest sectoral risk. In fact, the yield in trading stocks does not depend on what stocks we buy, but it depends on when we buy and when we sell. No matter how good a stock is, if we buy at a high price, the possibility of correction is very big.

\section{CONCLUSION}

Risk mitigation during the Covid-19 Pandemic ia very important because almost all stocks down so the potential returns were not balanced with investment risk, therefore the role of risk management is the key to successful investment during the Covid-19 Pandemic. We found that trade and consumer sectors arebthe safest sectors for the investors because trade and consumer goods always needed from time to time even in the pandemic era. The risk gap of sectoral refer to the level of risk during abnormal condition, include cofid19 Pandemic.

Based the risk mitigation we suggest that investors should consider invest in trade and consumer sectors shares to minimize risk. Besides investors should not Choose stocks whose daily trading volume is usually small, but has suddenly increased, is a sign of an entry dealer. Enter gradually with a guerrilla system. 


\section{REFERENCES}

Alhazami, L. (2020), Valuasi Saham yang Masih Layak untuk Dikoleksi di Bursa Efek Indonesia (BEI) pada Saat Pandemik Covid-19, Jurnal Ilmiah Akuntansi dan Keuangan Vol. 9 No.2, 139-149

Andrew W. L., Mamaysky, H., Jiang W. (2000), Foundations of Technical Analysis: Computational Algorithms, Statistical Inference, and Empirical Implementation,The Journal of Finance Vol. LV No. 4

Dilla, S., Sari, L.K. \& Achsani, N.A. (2020), Estimating The Effect Of The Covid-19 Outbreak Events On The Indonesia Sectoral Stock Return, Jurnal Aplikasi Manajemen dan Bisnis, Vol. 6 No. 3

Kiky, A. (2020). Manajemen Resiko Terhadap Black Swan Event 2020 di Indonesia (Studi Kasus Efek Covid-19). Jurnal Bina Manajemen. Vol. 8 No. 2 hal. 90 - 10.5

Qing H., Junyi L., Sizhu W. \& Jishuang Y. (2020), The impact of COVID-19 on stock markets, Economic and Political Studies, Volume 8, 2020 Pages 275-288

Riva'i, Hasan M., Junaedi, (2020) Pengaruh Peristiwa Pandemi Covid-19 terhadap Indeks Harga Saham Gabungan, E-JRA Vol. 09 No. 06 Agustus

Saleh, D.Z. (2009), Expected Return dan Resiko Consumer Based Asset Pricing Model Pasar Saham Indonesia, Jurnal Integritas Manajemen dan Bisnis Vol. 3 No. 1 April 2010: 33-52

Sunarso (2015), Introduksi Indikator Baru untuk Mengelola Resiko Investasi Portofolio di Bursa Efek Indonesia, Jurnal Manajemen dan Kewirausahaan, Vol 12 No. 2

-------, 2016, Membangun Jiwa Wiraswasta di Pasar Modal melalui Manajemen Resiko, Prosiding Seminar Nasional ke-2, Vol. 2 No. 1

Taufik, Ayuningtyas, E.A. (2020), Dampak Pandemi Covid 19 terhadap Bisnis dan Eksistensi Platform Online, Jurnal Pengembangan Wiraswasta, Vol. 22, No.1, DOI: http://dx.doi.org/10.33370/jpw.v22i01.389 